\title{
D-Asp upregulates PREP and GluA2/3 expressions and induces p-ERK1/2 and p-Akt in rat testis
}

\author{
Alessandra Santillo ${ }^{1, *}$, Massimo Venditti ${ }^{2, *}$, Sergio Minucci², Gabriella Chieffi Baccari ${ }^{1}$, \\ Sara Falvo', Luigi Rosati ${ }^{3}$ and Maria Maddalena Di Fiore ${ }^{1}$ \\ ${ }^{1}$ Dipartimento di Scienze e Tecnologie Ambientali, Biologiche e Farmaceutiche, Università degli Studi della \\ Campania 'Luigi Vanvitelli', Caserta, Italy, ${ }^{2}$ Dipartimento di Medicina Sperimentale, Sez. Fisiologia Umana e Funzioni \\ Biologiche Integrate, Università degli Studi della Campania 'Luigi Vanvitelli', Napoli, Italy and ${ }^{3}$ Dipartimento di \\ Biologia, Università degli Studi di Napoli Federico II, Napoli, Italy
}

Correspondence should be addressed to S Minucci; Email: sergio.minucci@unicampania.it

*(A Santillo and M Venditti contributed equally to this work)

\begin{abstract}
D-Aspartate (D-Asp) is an endogenous amino acid that plays a central role in the development of the central nervous system (CNS) and functioning of the neuroendocrine system. In line with its functions, it is abundantly present in the CNS and reproductive systems of vertebrates and invertebrates. It has been implicated in the biosynthesis and/or secretion of hormones and factors that are involved in various reproductive functions, such as GnRH from the hypothalamus and testosterone from the testis. We conducted an in vivo study consisting of acute (i.p. injection of $2 \mu \mathrm{mol} / \mathrm{g}$ body weight) and chronic (15 days drinking solution) administration of D-Asp to adult rats to understand the signaling pathways elicited by D-Asp in the rat testis. We found that D-Asp upregulated the expression of prolyl endopeptidase (PREP), a serine protease having a pivotal role in the regulation of mammalian spermatogenesis and spermiogenesis. Immunofluorescence analysis revealed its overexpression in Leydig cells, Sertoli cells and spermatogonia. Moreover, PREP was found to co-localize with GluA2/3, an AMPA receptor subunit, whose protein expression also increased after D-Asp treatments. Finally, we found a significant increase in ERK and Akt activities in the testis of rats treated with D-Asp. Since PREP is known to be involved in regulating GnRH levels and in germ cell differentiation, we hypothesize D-Asp to play a pivotal role in regulating hormone homeostasis and spermatogenesis through activation of PREP, AMPAR, ERK and Akt.

Reproduction (2019) 158 357-367
\end{abstract}

\section{Introduction}

D-Aspartate (D-Asp) is an endogenous amino acid with multifunctional roles. Its presence in the central nervous system (CNS) and reproductive systems of vertebrates and invertebrates (D'Aniello 2007, Raucci \& Di Fiore 2009, Di Giovanni et al. 2010a, Burrone et al. 2012, Santillo et al. 2013, Di Fiore et al. 2016a,b) is indicative of the functional role it plays in these systems. In the brain, it is primarily concentrated in the synaptic vesicles and axon terminals, suggesting its possible role as a neurotransmitter or neuromodulator (Spinelli et al. 2006, Topo et al. 2010). The high levels of D-Asp have also been detected in the vertebrate testis (Lamanna et al. 2007a,b, Burrone et al. 2010, Santillo et al. 2014, 2018). Specifically, D-Asp has been found to be located in Leydig cells (LC), Sertoli cells (SC), as well as in germ cells (GC), notably in spermatogonia (SPG), elongate spermatids (SPT) (Tomita et al. 2016) and spermatozoa (SPZ) of rats (Sakai et al. 1998) and humans (D'Aniello et al. 2005). Several studies report that both i.p. and oral administration of D-Asp to adult rats results in its accumulation in the testis, which is followed by increased levels of luteinizing hormone, progesterone and testosterone in the testis and serum ( $\mathrm{D}^{\prime}$ Aniello et al. 2000a,b, Topo et al. 2009, Santillo et al. 2014).

Evidence from literature indicates that D-Asp induces spermatogenesis not only by acting on the hypothalamus-pituitary-testis axis, but also through its direct action on the $\mathrm{LC}$, thereby increasing the synthesis of testosterone ( $\mathrm{D}^{\prime}$ Aniello et al. 1998 2000a,b, Topo et al. 2009, Di Fiore et al. 2014, 2016a,b, Santillo et al. 2014). Interestingly, D-Asp has also been known to directly affect the spermatogonial mitotic activity (Santillo et al. 2016) and is involved in the maturation of SPZ (Falvo et al. 2016).

Finally, recent studies suggest that D-Asp is recognized by glutamate receptors (GluRs) (Di Giovanni et al. 2010b, D'Aniello et al. 2011), including the ionotropic $\alpha$-amino-3-hydroxy-5-methyl-4-isoxazole propionic acid receptor (AMPAR). These findings have been confirmed by immunolocalization analysis, 
demonstrating the expression of GluA2/3, an AMPAR subunit in the SPG and LC of the rat testis (Gill et al. 2000, Gill \& Pulido 2001).

A number of factors are involved in the regulation of mammalian spermatogenesis and spermiogenesis (Izzo et al. 2011, Pariante et al. 2016, Nishimura \& L'Hernault 2017, Venditti \& Minucci 2017). Among these factors, considerable interest has been given to the protein prolyl endopeptidase (PREP) (Kimura et al. 1998, 2002, Valdivia et al. 2004, Dotolo et al. 2016, Venditti \& Minucci 2019). This enzyme belongs to the serine protease family and has a cleaving activity at the carboxyl terminal of proline residues of several peptide hormones and neuropeptides (Szeltner \& Polgár 2008).

Several studies have reported PREP to have functional roles in the CNS (Wilk 1983, Mentlein 1988); however, other reports suggest its involvement in reproductive processes (Kimura et al. 1998, 2002, Valdivia et al. 2004). In particular, we recently demonstrated, for the first time, the requirement of this enzyme for a normal reproductive function; moreover, the lack of functional activity of this enzyme may lead to marked alterations of the gonads and, ultimately, gametes (Dotolo et al. 2016).

A direct role of PREP in both steroidogenesis and spermatogenesis has been hypothesized. Indeed, PREP has been reported to possess a specific action in limiting GnRH stimulation of the pituitary gonadotropes and cleaving its C-terminal glycinamide residue, as demonstrated in rat and ovine hypothalamic extracts (Lew et al. 1994, Yamanaka et al. 1999). Further, PREP plays a role in the morphological remodeling, occurring in the first wave of rat spermatogenesis, a function attributed to its co-localization with tubulin in the cytoplasm of SC and GC, as well as in the nucleus of SPG and SPC, suggesting its role in the proliferative phases of spermatogenesis (Venditti \& Minucci 2019).

Despite a growing body of literature on D-Asp and its role in the spermatogenesis, limited studies have been conducted to understand the underlying molecular pathways responsible for the action of D-Asp in the rat testis. Since, as aforementioned, D-Asp and PREP affects the proliferation of GC and are involved in the steroidogenesis, in the present study, we examined the effects of intraperitoneal or oral administration of D-Asp on PREP protein expression in adult rats. Further, since PREP may be involved in the proliferative phases of rat spermatogenesis, and since D-Asp, following its interaction with AMPAR, induces phosphorylation of ERK and Akt, we investigated the effects of treatment of D-Asp on GluA2/3, p-ERK, and p-Akt and the possible participation of PREP in such diversified pathways.

\section{Materials and methods}

\section{Animals and experiments}

Male Wistar rats (Rattus norvegicus), weighing 300 to $350 \mathrm{~g}$, were kept under regulated conditions of temperature $\left(24 \pm 2^{\circ} \mathrm{C}\right)$ and lighting (12-h light and 12-h darkness cycles). They received commercial food pellets ad libitum. We performed two different experiments: Experiment 1 (chronic treatment): rats $(n=10)$ were divided into two groups: the first group was allowed to drink a solution consisting of $20 \mathrm{mM}$ D-aspartate (D-Asp; SigmaAldrich) for 15 days (Santillo et al. 2014); rats in the second group (control) were given fresh water for 15 days. At the end of the treatment, in the early daylight hours, rats were first anesthetized by an i.p. injection of chloral hydrate (Sigma-Aldrich) and then killed. Experiment 2 (acute treatment): rats $(n=20)$ were injected i.p. with $2.0 \mu \mathrm{mol} / \mathrm{g}$ body weight D-Asp dissolved in a saline solution. The dose was selected on the basis of preliminary experiments performed using different doses $(0.5-4.0 \mu \mathrm{mol} / \mathrm{g}$ body weight) of D-Asp (Raucci et al. 2005, Santillo et al. 2006, 2011, Monteforte et al. 2007, 2009), whereas control rats $(n=5)$ received saline injection. The animals ( $n=5$ for each time) were anesthetized by an i.p. injection of chloral hydrate $(40 \mathrm{mg} / 100 \mathrm{~g}$ body weight) and then killed at different time points (30 min, $2 \mathrm{~h}$, and $5 \mathrm{~h}$ ) after the amino acid injection.

The testes were dissected out, weighed and rapidly immersed in Bouin's fluid (solution of picric acid, glacial acetic acid and formaldehyde; BioOptica, Milan, Italy) and liquid nitrogen (SOL; Caserta, Italy) for histochemical and biochemical analyses, respectively. The experimental protocol and the housing conditions were in accordance with the Italian guidelines (D.Lvo 116/92) and authorized by the Local Animal Care Committee (Servizio veterinario ASL 44, Prot. Vet. 22/95).

\section{Preparation of samples for D-Asp analysis}

Testis samples were homogenized with $0.5 \mathrm{M}$ perchloric acid (PCA; Sigma-Aldrich) in a ratio of 1:10. They were then centrifuged at $30000 \mathrm{~g}$ for $20 \mathrm{~min}$. The supernatants were neutralized with $5 \mathrm{M} \mathrm{KOH}$ (Sigma-Aldrich) to $\mathrm{pH}$ 7.5-8.5. The samples were then cooled for $30 \mathrm{~min}$ at $0^{\circ} \mathrm{C}$ to allow the maximum precipitation of potassium perchlorate (formed by the reaction between PCA and $\mathrm{KOH}$ ) and then they were centrifuged as above. The supernatants were brought to a $\mathrm{pH}$ of about 2.5 with $1 \mathrm{M} \mathrm{HCl}$ (Sigma-Aldrich), and the amino acids were purified on a cation exchange column $(1 \# 3 \mathrm{~cm}$ ) (AG $50 \mathrm{~W}-\mathrm{X} 8$ resin, hydrogen ionic form, 200-400 mesh obtained from BioRad laboratories), previously regenerated by washing the resin with an excess of $2 \mathrm{M} \mathrm{NaOH}$ (Sigma-Aldrich), then with distilled water, then with an excess of $4 \mathrm{M} \mathrm{HCl}$, and finally equilibrated with $0.01 \mathrm{M} \mathrm{HCl}$. After absorption of the samples, the columns were washed with $10 \mathrm{~mL} 0.01 \mathrm{M} \mathrm{HCl}$. Finally, the amino acids were eluted with $8 \mathrm{ml} 4 \mathrm{M} \mathrm{NH}_{4} \mathrm{OH}$ (SigmaAldrich). These eluates were evaporated (in small Petri dishes) on a hot-plate at $40-60^{\circ} \mathrm{C}$, under a hood. The residues were dissolved in $1 \mathrm{~mL} \mathrm{HCl} 0.01 \mathrm{M}$ and further purified on a Sep-pak cartridge C-18 (300 mg; Waters, Milan, Italy) as follows. The samples were passed slowly through the cartridges (previously activated with methanol or acetonitrile and then washed with distilled water) with a syringe, and then the cartridges were eluted twice with $2 \mathrm{~mL} 0.1 \mathrm{M} \mathrm{HCl}, \mathrm{pH} 8.2$, to recover all the amino acids. Both eluates were combined and dried using a Savant centrifuge or left to evaporate in small Petri dishes at $40-50^{\circ} \mathrm{C}$ under the hood. Finally, the residues were dissolved in $200 \mu \mathrm{L} 0.01 \mathrm{M} \mathrm{HCl}$ and analyzed for the presence of $D$-Asp. 


\section{Enzymatic uv method for the determination of D-Asp}

D-aspartic acid was specifically assayed in rat testis of both chronic and acute experiments by oxidation with D-aspartate oxidase enzyme (D-AspO) (EC 1.4.3.3.) and measurements of the oxaloacetate were made by means of a coupling reaction with NADH (Sigma-Aldrich) and malate dehydrogenase (MDH) (Sigma-Aldrich) according to the method of D'Aniello and Giuditta (1977), which was based on the following principle:

$$
\begin{aligned}
\text { D-Asp } & +\mathrm{O}_{2}+\mathrm{H}_{2} \mathrm{O}-\mathrm{D} \text {-AspO }-\alpha \text {-oxaloacetate } \\
+ & \mathrm{NH}_{3}+\mathrm{H}_{2} \mathrm{O}_{2} \\
\alpha \text {-Oxaloacetate } & +\mathrm{NADH}+\mathrm{H}-\mathrm{MDH}-\text { L-malate } \\
+\mathrm{NAD} &
\end{aligned}
$$

The decrease in NADH was measured by the change in optical density at $340 \mathrm{~nm}$. In brief, $0-400 \mu \mathrm{L}$ sample to be analyzed (previously brought to $\mathrm{pH}$ 7.5-8.5) were put in an Eppendorf tube and mixed with distilled water to a final volume of $400 \mu \mathrm{L}$. After that, $40 \mu \mathrm{L} 2 \mathrm{M}$ Tris- $\mathrm{HCl}$ (2 M) (Sigma-Aldrich) $\mathrm{pH} 8.2,40 \mu \mathrm{L} \mathrm{NADH}$ (solution $2 \mu \mathrm{mol} / \mathrm{mL}$, in Tris- $\mathrm{HCl} 0.2 \mathrm{M}$, $\mathrm{pH}$ 8.2) and $2 \mu \mathrm{L} \mathrm{MDH}(5000 \mathrm{IU} / \mathrm{mL})$ were added and the assay mixture was mixed and incubated at $37^{\circ} \mathrm{C}$ for $10 \mathrm{~min}$ (this served to eliminate endogenous oxaloacetate present in the sample). After the incubation, the sample was centrifuged at $30000 \mathrm{~g}$ for $5 \mathrm{~min}$. The supernatant was transferred to a microcuvette and the absorbance was read at $340 \mathrm{~nm}$ against distilled water. Thereafter, $2 \mu \mathrm{L}$ D-AspO $(5 \mathrm{mg} / \mathrm{mL}$, purified from the hepatopancreas of Octopus vulgaris; D'Aniello \& Giuditta 1977) were added to the assay mixture, mixed and incubated for $10 \mathrm{~min}$ at $37^{\circ} \mathrm{C}$. After incubation, the tube was centrifuged as above and the supernatant was read again at $340 \mathrm{~nm}$. For a blank sample the same procedure was used, except that D-AspO was not added. The same procedure was used for a standard sample, except that $100 \mu \mathrm{L}$ D-Asp standard in a concentration of $1 \mu \mathrm{mol} / \mathrm{mL}$ and distilled water to a volume of $400 \mu \mathrm{L}$ was used instead of sample.

\section{Antibodies}

Antibodies were purchased from the following sources: (1) anti-GluA2/3 (\#07-598; Merck Millipore); (2) anti-PREP (\#ab58988; Abcam); (3) anti-phospho-ERK1 (\#9101; Cell Signaling Technology, Inc.); (4) anti-ERK1/2 (\#sC-93; Santa Cruz Biotechnology, Inc.); (5) anti-phospho-Akt (\#4060; Cell Signaling Technology, Inc.); (6) anti-Akt (\#9272; Cell Signaling Technology, Inc.); (7) anti- $\beta$-actin (\#sc-81178; Santa Cruz Biotechnology); IgG from rabbit serum (\#15006; Sigma-Aldrich).

\section{Protein extraction and Western blot analysis}

Rat testis extracts were lysed in lysis buffer (Sigma-Aldrich) containing $50 \mathrm{mM}$ Tris- $\mathrm{HCl}(\mathrm{pH} 7.5), 5 \mathrm{mM}$ EDTA, $300 \mathrm{mM}$ $\mathrm{NaCl}, 150 \mathrm{mM} \mathrm{KCl}, 1 \mathrm{mM}$ dithiothreitol, 1\% Nonidet P40 in PBS (13.6 mM NaCl; $2.68 \mathrm{mM} \mathrm{KCl} ; 8.08 \mathrm{mM} \mathrm{Na}_{2} \mathrm{HPO} 4 ; 18.4 \mathrm{mM}$

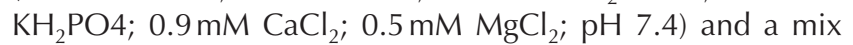
of protease inhibitors (Sigma-Aldrich) $(4 \mu \mathrm{g} / \mu \mathrm{L}$ of leupeptin, aprotinin, pepstatin A, chymostatin, phenylmethylsulfonyl fluoride (PMSF), and $5 \mu \mathrm{g} / \mu \mathrm{L}$ of tosyl phenylalanyl chloromethyl ketone $(\mathrm{TPCK}))$ The protein extracts $(40 \mu \mathrm{g})$ were boiled in Laemmli sample buffer (BioRad), separated using a $9 \%$ SDS-PAGE and transferred onto a nitrocellulose membrane (BioRad). The complete transfer was assessed using a prestained protein marker (BioRad). Membranes were first treated for $1 \mathrm{~h}$ with a blocking solution ( $5 \%$ non-fat powdered milk in $25 \mathrm{mM}$ Tris, $\mathrm{pH} 7.4 ; 200 \mathrm{mM} \mathrm{NaCl}$; $0.5 \%$ Triton X-100, TBS/ Tween) (Sigma-Aldrich) and then incubated overnight at $4{ }^{\circ} \mathrm{C}$ with the primary antibody: (1) anti-GluA2/3 (diluted 1:3000); (2) anti-PREP (diluted 1:3000); (3) anti-phospho-ERK1 (diluted 1:1000); (4) anti-ERK1/2 (diluted 1:3000); (5) anti-phosphoAkt (diluted 1:2000); (6) anti-Akt (diluted 1:2000) and (7) anti- $\beta$-actin (diluted 1:2000). After washing thrice with TBS/ Tween, the membranes were incubated with horseradish peroxidase-conjugated secondary antibody (Sigma-Aldrich) diluted 1:5000 in the blocking solution for $1 \mathrm{~h}$ at room temperature. Then, membranes were washed again thrice in TBS/Tween and the immunocomplexes were detected using an enhanced chemiluminescence (ECL) system (Amersham Bioscience). Protein bands were then quantified using the Image J, a free software for digital image processing, based on Sun-Java, developed by the National Institutes of Health of the United States.

Specificity of PREP antiserum was checked by preadsorbing primary antiserum with five-fold excess of the corresponding epitope (prolyl endopeptidase peptide, \#ab63973; Abcam).

\section{Immunofluorescence analysis of rat testis}

In order to study the cellular localization of PREP and GluA2/3, $5 \mu \mathrm{m}$ testis sections were dewaxed, rehydrated and processed as described by Chemek et al. (2018) and Venditti et al. (2018). Briefly, antigen retrieval was performed by pressure cooking of the slides for $3 \mathrm{~min}$ in $0.01 \mathrm{M}$ citrate buffer $(\mathrm{pH}$ 6.0). Then, the slides were incubated with $0.1 \%(\mathrm{v} / \mathrm{v})$ Triton X-100 in PBS for $30 \mathrm{~min}$. Later, non-specific-binding sites were blocked by incubating the slides in normal serum (Sigma-Aldrich) (diluted 1:5 in PBS containing 5\% (w/v) BSA (Sigma-Aldrich)) before the addition of anti-PREP or anti-GluA2/3 antibody $(1: 100)$ overnight at $4^{\circ} \mathrm{C}$. Following incubation with primary antibody, slides were washed with PBS and incubated for $1 \mathrm{~h}$ with PNA lectin (1:50) to stain the acrosome (Alexa Fluor 568; Invitrogen) and appropriate secondary antibody (Alexa Fluor 488; Invitrogen, FITC-Jackson, ImmunoResearch) diluted 1:500 in the blocking solution. Slides were mounted using Vectashield + DAPI (Vector Laboratories; Peterborough, UK) for nuclear staining, and then observed under a microscope (Leica DM 5000 B + CTR 5000). The images were captured and saved with Leica IM 1000 software (Leica).

For GluA2/3 co-localization with PREP or p-ERK 1/2 or $\mathrm{p}$-Akt, $5 \mu \mathrm{m}$ testis serial sections were processed as described earlier, using antibodies diluted 1:100 in the blocking solution.

To be sure about the specificity of the used antisera, we performed different controls by (1) incubating the samples with rat isotype $\operatorname{lgG}$, used at the same concentration as antibodies; (2) omitting the primary antibody and, in the case of PREP antibody; (3) using the preadsorbed antiserum with the appropriate epitope, as described in the Western blot section. 


\section{Statistical analysis}

We used ANOVA followed by Student-Newman-Keuls's test to evaluate significant changes between the experimental groups. The differences were considered statistically significant at $P<0.05$. All data were expressed as the mean \pm standard deviation (s.D.).

\section{Results}

\section{Chronic treatment}

$D$-Asp levels in rat testis and its accumulation in response to chronic treatment

Following chronic D-Asp treatment (drinking a solution of $20 \mathrm{mM}$ D-Asp for 15 days) testis D-Asp levels $(760 \pm 55 \mathrm{nmol} / \mathrm{g}$ tissue) were significantly higher with respect to the controls $(103 \pm 9 \mathrm{nmol} / \mathrm{g}$ tissue).
Effects of oral administration of D-Asp on testicular PREP and GluA2/3 expression

The oral administration of D-Asp induced a significant increase in the expression of PREP as compared to that in the control rats (Fig. 1A and B). Similarly, expression of GluA2/3 was significantly more elevated in D-Asptreated rats than that in control rats (Fig. $1 \mathrm{~A}$ and C). Protein samples extracted from control rat testis incubated with the PREP antiserum preadsorbed with the corresponding epitope did not give any signal, confirming the specificity of the antibody through competitive peptide blocking (Supplementary Fig. 4A, see section on supplementary data given at the end of this article).

These data are supported by immunofluorescence studies (Fig. 1D, a and c) that revealed an increased immunofluorescent signal of both PREP (Fig. 1D, b) and GluA2/3 (Fig. 1D, d) in D-Asp-treated testes. In particular,

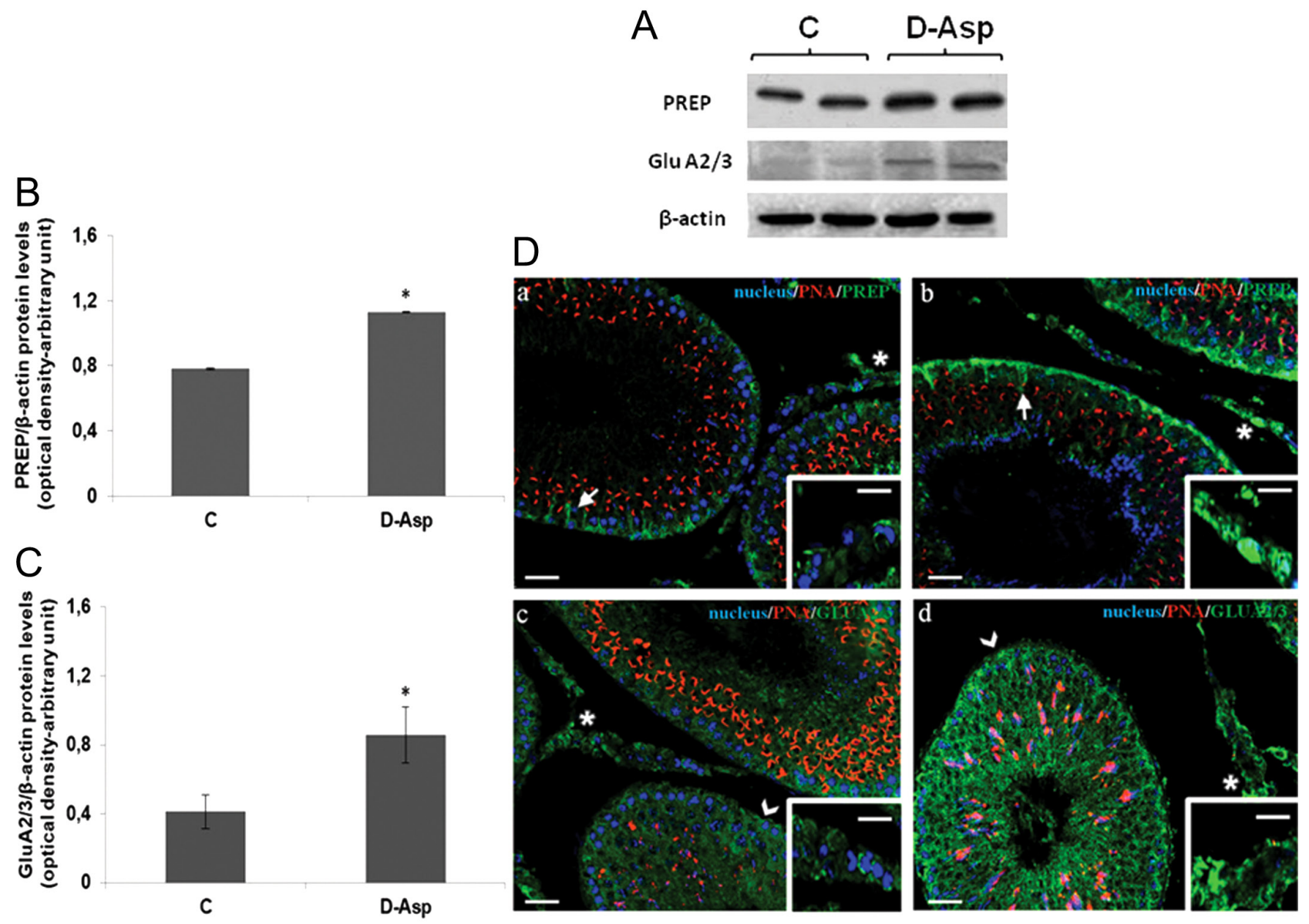

Figure 1 Expression and localization of PREP and GluA2/3 after chronic D-Asp treatment. (A) Western blot analysis of PREP and GluA2/3 expression in the testis from D-Asp-treated and control rats. (B) The amount of PREP was quantified using ImageJ program and normalized with respect to $\beta$-actin (see A). (C) The amount of GluA2/3 was quantified using the ImageJ program and normalized with respect to $\beta$-actin (see A). Values represent the means \pm S.D. of five samples (two bands shown in upper panel). ${ }^{*} P<0.05$ vs controls. (D). Localization of PREP and GluA2/3 in the testis from D-Asp-treated rats (b, d) and controls ( $a, c)$. a, b: PREP fluorescence (green), DAPI-fluorescent nuclear staining (blue), PNA lectin acrosome staining (red). c, d: GluA2/3 fluorescence (green), DAPI-fluorescent nuclear staining (blue), PNA lectin acrosome staining (red). The images in the insets were captured at $\times 40$ magnification, all the others at $\times 20$ magnification. Scale bars represent $20 \mu \mathrm{m}$, except for the insets, where they represent $10 \mu \mathrm{m}$. Asterisks: Leydig cells; Arrowheads: Spermatogonia; Arrows: Sertoli cells. 
we observed that PREP was mainly localized to the cytoplasm and nucleus of mitotic and meiotic cells, as well as in the cytoplasm of elongating spermatids (SPTs) and Sertoli cells (SCs; arrows in Fig. 1D, a and b). The staining was also detected in the cytoplasm of the Leydig cells (LCs, asterisk, Fig. 1D, a and b and insets). GluA2/3 was expressed in all stages and, to varying extent, in all cell types; however, its immunopositivity was prevalently localized within the spermatogonia (SPG; arrowhead in Fig. 1D, c and d and inset) and the LC (asterisks, Fig. 1D, c and d and inset). Finally, also immunofluorescence study performed using PREP antiserum preadsorbed with the epitope on testis section of control rat did not give any signal, confirming the specificity of the antibody through competitive peptide blocking (Supplementary Fig. 4B).

\section{Effects of oral administration of D-Asp on testicular p-ERK $1 / 2$ and p-Akt expressions}

We found the basal expression levels of ERK1 protein to be higher than those of ERK2 in the testis of both D-Asp-treated rats and control rats (Fig. 2A and B). Moreover, these remained unchanged following D-Asp administration. On the contrary, both phosphorylated ERK1 and ERK2 levels were significantly higher in the testes of rats treated with D-Asp as compared to the levels in the testes of control rats (Fig. 2A and B).

Moreover, as reported in Fig. 2C and D, D-Asp administration led to a significant increase in the expression of phosphorylated Akt (p-Akt). However, the basal levels of Akt protein expression remained unaltered following D-Asp administration.

\section{Acute treatment}

\section{$D$-Asp levels in rat testis and its accumulation in response to acute treatment}

After i.p. injection of D-Asp ( $2.0 \mu \mathrm{mol} / \mathrm{g}$ body weight) testis D-Asp concentration was significantly higher than those of basal values $(96 \pm 11 \mathrm{nmol} / \mathrm{g}$ tissue). Particularly, testis D-Asp levels were $254 \pm 19 \mathrm{nmol} / \mathrm{g}$ tissue after $30 \mathrm{~min}$ from treatment, $460 \pm 35 \mathrm{nmol} / \mathrm{g}$ tissue after $2 \mathrm{~h}$ and $290 \pm 24 \mathrm{nmol} / \mathrm{g}$ tissue after $5 \mathrm{~h}$.

\section{Effects of i.p. administration of D-Asp on testicular PREP expression}

We used Western blotting to analyze the PREP levels in the testes of D-Asp-treated and control rats (Fig. $3 \mathrm{~A}$ and $\mathrm{B})$. A significant increase in the levels of PREP protein was observed at $30 \mathrm{~min}$ and $2 \mathrm{~h}$ after D-Asp administration. After $5 \mathrm{~h}$ following D-Asp administration, the levels of PREP protein returned to the basal value (Fig. $3 \mathrm{~A}$ and $\mathrm{B}$ ).

In order to better characterize the modulation of PREP expression by D-Asp, immunofluorescence analysis was

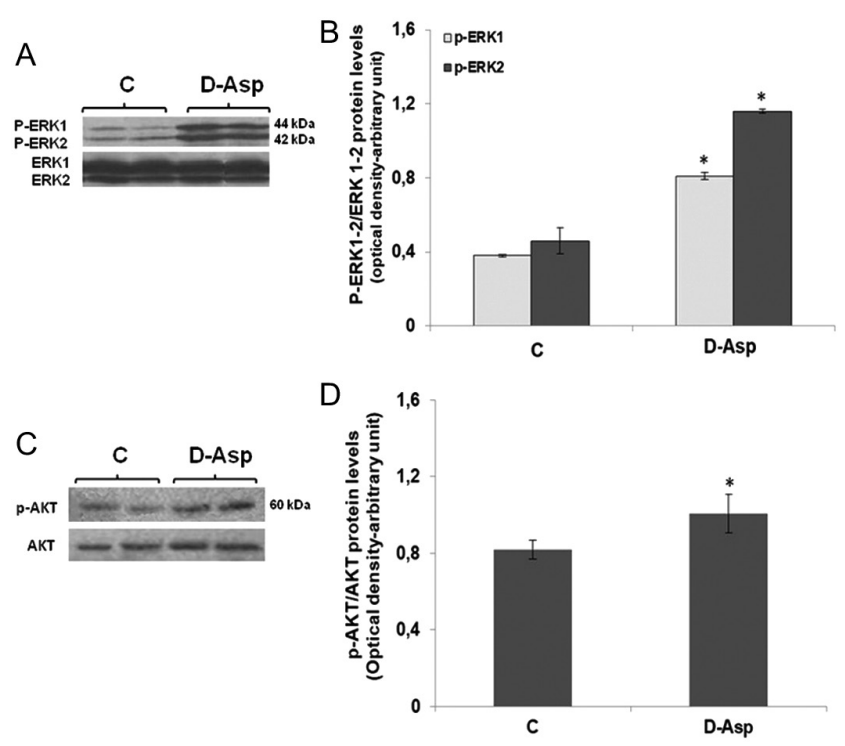

Figure 2 Expression of p-ERK $1 / 2$ and p-Akt after chronic D-Asp treatment. (A) Detection of P-ERK1 and P-ERK2 proteins in the testis from D-Asp-treated rats and controls by Western blot. (B) The amounts of phosphorylated ERK1 and ERK2 were quantified using ImageJ program and normalized with respect to ERK1 and ERK2, respectively (see A). Values represent the means \pm S.D. of five samples (two bands shown in upper panel). $* P<0.05$ vs controls. (C) Western blot analysis of Akt protein in the testis from D-Asp-treated and control rats. (D) The amount of phosphorylated Akt was quantified using the ImageJ program and normalized with respect to Akt (see C). Values represent the means \pm S.D. of five samples (two bands shown in upper panel). ${ }^{*} P<0.05$ vs controls.

performed (Fig. 3C). As described earlier, PREP showed a comparable expression pattern in the testes of control rats (Fig. 3C, a) and at $5 \mathrm{~h}$ (Fig. 3C, d), confirming its localization in the cytoplasm and the nucleus of SPG and spermatocytes, as well as in the cytoplasm of elongating SPT and SC (arrows in Fig. 3C). Immunoreactivity was also detected in the cytoplasm of the LC (asterisk, Fig. 3C, and insets). This expression pattern was comparable to all time points analyzed; however, a more intense signal was observed in SC and LC cytoplasm after 30 min (arrows and asterisks, Fig. 3C, b and insets) and $2 \mathrm{~h}$ (arrows and asterisks, Fig. 3C, c and insets) following D-Asp administration, as evident from the results of Western blotting.

\section{Effects of i.p. administration of D-Asp on testicular GluA2/3 expression}

D-Asp affected the expression of GluA2/3 protein in the rat testis (Fig. $4 \mathrm{~A}$ and B). Particularly, the administration of D-Asp significantly induced an increase of GluA2/3 protein expression at $5 \mathrm{~h}$ with respect to its levels in control rats (Fig. 4A and B). The immunofluorescence analysis confirmed this finding (Fig. 4C).

Similarly, to the results obtained for chronic treatment, we observed that GluA2/3 immunopositivity was 
A

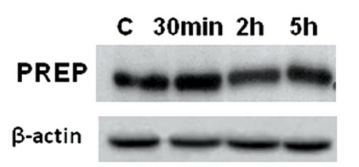

C
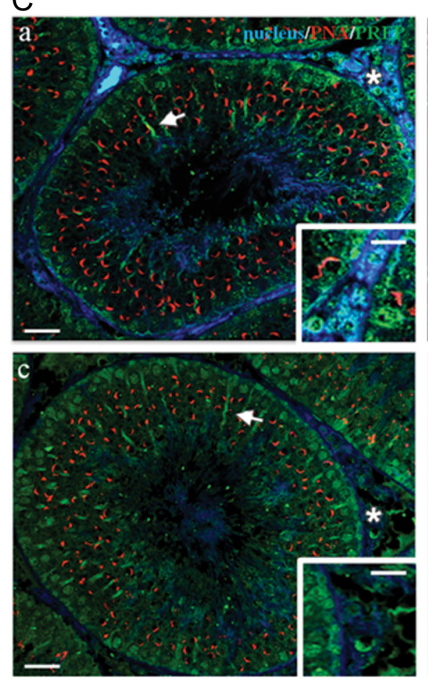
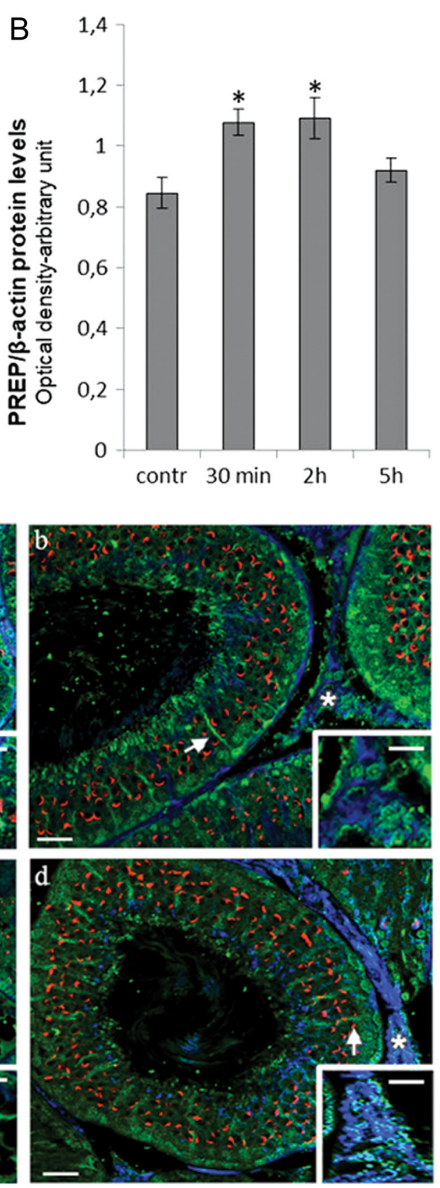

Figure 3 Expression and localization of PREP after acute D-Asp treatment. (A) Detection of PREP protein by Western blot in the testis of D-Asp-treated and control rats. (B) The amount of PREP was quantified using the Image program and normalized with respect to $\beta$-actin (see A). Values represent the means \pm S.D. of five samples (one band shown in the upper panel). ${ }^{*} P<0.05$ vs controls. (C)

Immunofluorescence analysis for PREP in rat testis from controls (a) and at $30 \mathrm{~min}$ (b), $2 \mathrm{~h}$ (c) and $5 \mathrm{~h}$ (d) from D-Asp treatment. a, b, c, d: PREP fluorescence (green), DAPI-fluorescent nuclear staining (blue), PNA lectin acrosome staining (red). The images in the insets were captured at $\times 40$ magnification, all the others at $\times 20$ magnification. Scale bars represent $20 \mu \mathrm{m}$, except for the insets, where they represent $10 \mu \mathrm{m}$. Asterisks: Leydig cells; Arrows: Sertoli cells.

prevalently localized within the SPG (arrowheads, Fig. 4C, a and inset) and the LC (asterisks, Fig. 4C, c and inset). After $5 \mathrm{~h}$ from D-Asp administration, the fluorescent signal increased inside these cell types as compared to the signal in the control cells (Fig. 4C, b and d, better highlighted in the inset). To have more details concerning PREP and GluA2/3 localization, we performed a double immunofluorescence staining study of the two proteins, using testis serial sections. We confirm the localization pattern found in the single staining: PREP was detected mainly in SC cytoplasmic protrusions, SPG nucleus and in the interstitial compartment, GluA2/3 showed a more diffused localization, being expressed throughout the seminiferous epithelium, as well as in LC. However,

their co-localization, particularly in the cytoplasm of $\mathrm{LC}$, appeared to be very mild, as noticeable by the intermediate yellow-orange tint given by the merge of the images (Supplementary Fig. 1). This co-localization pattern is similar between the acute (Supplementary Fig. $1 \mathrm{a}, \mathrm{b}$ and insets) and the chronic D-Asp treatment (Supplementary Fig. 1a, c and insets).

\section{Effects of i.p. administration of D-Asp on testicular $p$-ERK $1 / 2$ and $p$-Akt expressions}

The total protein isolated from the rat testes was analyzed by Western blotting to evaluate the activity of ERK and Akt (Fig. 5). The administration of D-Asp to rats induced a significant increase in the ERK2 activity at $2 \mathrm{~h}$ and both ERK $1 / 2$ activities at $5 \mathrm{~h}$ with respect to the activities in control rats (Fig. 5A and B). Moreover, D-Asp-treated rat testes showed a significant increase in the Akt activity (p-Akt) at $2 \mathrm{~h}$ as compared to its activity in the testes of control rats (Fig. 5C and D).

To provide insight to the signaling mechanism, we performed a co-localization study of GluA2/3 with p-ERK1/2 (Supplementary Fig. 2) and p-Akt (Supplementary Fig. 3). As described earlier, GluA2/3 was prevalently expressed in SC, SPG and LC cytoplasm, showing a more intense fluorescent signal in testis at $5 \mathrm{~h}$ after D-Asp treatment (Supplementary Fig. 2a, b, c and d). p-ERK1/2 showed the same sub-localization, as well as in luminal spermatozoa (Supplementary Fig. 2a, b, $\mathrm{c}$ and d). The intensity of the staining increased at $2 \mathrm{~h}$ and $5 \mathrm{~h}$ after D-Asp treatment, where the intermediate yellow-orange tint reflects the co-localization of the two proteins in SPG and LC (Supplementary Fig. 2c and d).

We found a comparable expression pattern for p-Akt that is extensively localized in the SC cytoplasm, along with SPG, SPC and LC (Supplementary Fig. 3a, b, c and d). The intermediate yellow-orange tint reflects the co-localization of p-Akt and GluA2/3 in the cytoplasm of the above-mentioned cells (Supplementary Fig. 3a, b, c and d).

Finally, to assess the specificity of all the used antibodies, we carried out negative control experiments, using rat isotype IgG (Supplementary Fig. 4C, a-e) either by omitting the primary antibody (Supplementary Fig. $4 \mathrm{C}, \mathrm{f}-\mathrm{j}$ ) on rat testis of both the acute and chronic D-Asp treatment.

\section{Discussion}

Steroidogenesis and spermatogenesis are processes that involve a complex interaction of a wide range of hormones and factors (Schlatt \& Ehmcke 2014, Griswold 2016) among which a considerable interest in the past two decades has been directed to the amino acid D-Asp (Di Fiore et al. 2014, 2016a,b, 2018). Several studies have reported that a chronic treatment, consisting in oral administration of D-Asp to adult rats, as well as an 
A
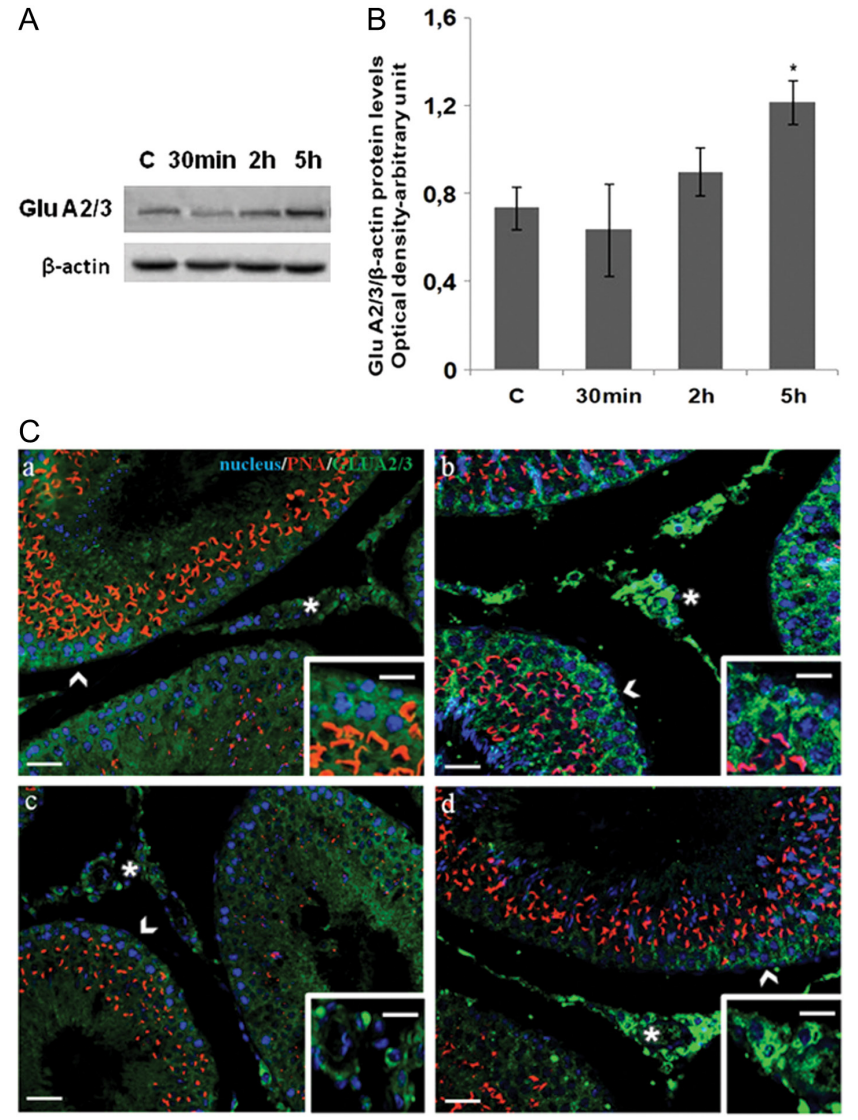

Figure 4 Expression and localization of GluA2/3 after acute D-Asp treatment. (A) Detection of GluA2/3 by Western blot in rat testis at various times after D-Asp treatment. (B) The amount of GluA2/3 was quantified using ImageJ program and normalized with respect to $\beta$-actin protein (see A). Values represent the mean \pm S.D. of five separate experiments (one band shown in upper panels). ${ }^{*} P<0.05$ vs controls. (C) Immunofluorescence analysis for GluA2/3 in rat testis from controls (a, c) and at $5 \mathrm{~h}$ after D-Asp treatment (b, d). a, b, c, d: GluA2/3 fluorescence (green), DAPI-fluorescent nuclear staining (blue), PNA lectin acrosome staining (red). The images in the insets were captured at $\times 40$ magnification, all the others at $\times 20$ magnification. Scale bars represent $20 \mu \mathrm{m}$, except for the insets, where they represent $10 \mu \mathrm{m}$. Asterisks: Leydig cells; Arrowheads: Spermatogonia.

acute treatment, through a single i.p. injection of D-Asp, results in the accumulation of this amino acid in the male gonads. Here, it induces spermatogenesis by increasing the testis/serum testosterone levels either through the hypothalamus-pituitary-testis axis or by acting directly on the LC (Nagata et al. 1999a,b, D'Aniello 2007, Di Fiore et al. 2014, 2016a,b).

D-Asp has been known to exert its effect on the steroidogenesis and spermatogenesis via several intracellular signaling pathways. For example, evidence suggests that D-Asp modulates steroidogenesis in the LC by inducing the adenylate cyclase-cAMP and ERK pathways (D'Aniello et al. 2007). Similarly, in SPG, D-Asp may directly activate proliferation through both MAPK and Akt pathways (Di Fiore et al. 2016b).
The present study aimed to characterize signaling pathways triggered by D-Asp in rat spermatogenesis.

The results obtained from a chronic treatment, consisting in oral administration of D-Asp to adult rats, as well as an acute treatment, through a single i.p. injection of D-Asp, confirmed that rat testis possesses the ability of rapidly uptaking D-Asp. Testis levels of the amino acid increased about seven times after chronic administration and reached a maximum increase of about four times after acute administration. Using Western blot and immunofluorescence analyses, our study revealed for the first time that chronic and acute administrations of D-Asp elicited the expression of PREP protein. The chronic D-Asp treatment induced an increase of approximately $37 \%$ in the expression levels of PREP protein. Moreover, the acute experiment indicated that PREP expression increased after $30 \mathrm{~min}$ and remained high until $2 \mathrm{~h}$ after the treatment. PREP is a serine protease that functions in reproductive processes (Dotolo et al. 2016, Venditti \& Minucci 2019). PREP was originally purified from the ascidian sperm (Yokosawa et al. 1983); it was later isolated from the herring testis by Yoshida et al. (1999). In mouse, PREP is localized in SPT and SPZ and has been hypothesized to be involved in sperm motility (Kimura et al. 2002). Later studies on humans demonstrated that PREP is localized in the seminiferous tubules and LC (Valdivia et al. 2004, Myöhänen et al. 2012). Finally, the absence of this enzyme in PREP-knockdown mice led to a marked alteration of the gonads and, ultimately, gametes, suggesting the indispensable role of the protein for correct reproductive functions (Dotolo et al. 2016).

Interestingly, it is reported that treatment of rat ovary cells with equine chorionic gonadotropin and treatment of cow granulosa cells with $\mathrm{GnRH}$ upregulate both the activity and mRNA levels of PREP to regulate the ovulatory process (Pereira et al. 2009, Tonellotto dos Santos et al. 2012). Furthermore, PREP appears to have a direct role in limiting the $\mathrm{GnRH}$ stimulation of the pituitary gonadotropes, thereby cleaving its C-terminal glycinamide residue as demonstrated in rat and ovine hypothalamic extracts (Lew et al. 1994, Yamanaka et al. 1999).

Several reports from the literature highlighted the potential of D-Asp to induce an increase in $\mathrm{GnRH}$ (D'Aniello 2007 for review). Thus, considering the fact that D-Asp is endogenously present in rat testis, we could hypothesize that enhanced PREP expression levels in D-Asp-treated gonads are required to counteract and limit the physiological threshold levels of $\mathrm{GnRH}$.

Furthermore, the immunofluorescence analysis showed a stronger PREP immunopositivity in the GC of D-Asp-treated rats as compared to that in the control rats. In particular, the protein was localized to the cytoplasm and the nucleus of mitotic and meiotic GC, as well as to the cytoplasm of elongating SPT and SC. Taking into account that PREP also seems to be involved in DNA synthesis (Ohtsuki et al. 1997, Ishino et al. 1998) and 

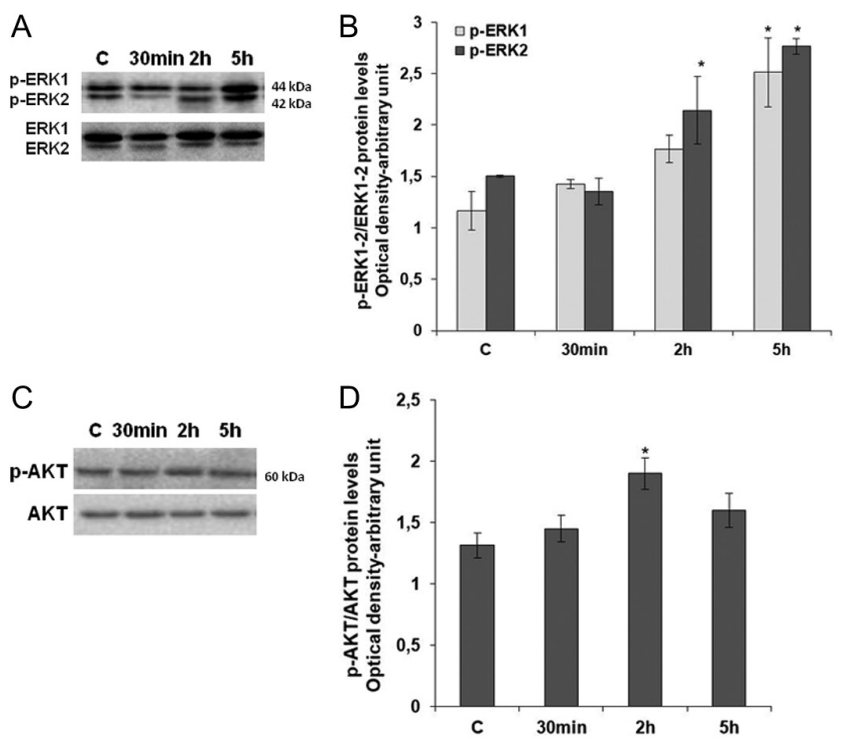

Figure 5 Expression of p-ERK1/2 and p-Akt after acute D-Asp treatment. (A) Analysis of rat testes with anti-phospho-ERK1/2 antibodies showing phosphorylation and activation of ERKs at various times after D-Asp treatment. Two specific bands, corresponding to the sizes of $44 \mathrm{kDa}$ and $42 \mathrm{kDa}$, respectively, were detected. (B) The amounts of activated ERK1/2 were quantified using ImageJ program and normalized with respect to total ERK1/2. Values represent the mean \pm S.D. of five separate experiments (one band shown in upper panels). ${ }^{*} P<0.05$ vs controls. (C) Western blot analysis of rat testes with anti-phospho-Akt antibody showing phosphorylation and activation of Akt at various times after D-Asp treatment. (D) The amount of activated Akt was quantified using Imagel program and normalized with respect to total Akt. Values represent the mean \pm S.D. of five separate experiments (one band shown in $\mathrm{C}) .{ }^{*} P<0.05$ vs controls.

in the meiotic and post-meiotic phases of germinal cell differentiation (Venditti \& Minucci 2019), the increased PREP testicular expression following D-Asp treatment strongly supports an active role of this protein in the spermatogenesis.

Although numerous efforts have been made to identify specific receptors for D-Asp in the nervous and endocrine systems until now we are far from understanding. Several reports indicate the ability of D-Asp to stimulate the same excitatory receptors of L-glutamate namely GluRs (Di Giovanni et al. 2010b, D'Aniello et al. 2011). Although the presence of GluRs is well documented in the CNS (Dingledine et al. 1999), several studies have demonstrated various subtypes of ionotropic GluRs (iGluRs), including NMDA, AMPA and kainate receptors as well as metabotropic GluRs (mGluRs) to be expressed in the rat and mouse testes (Gill et al. 2000, Gill \& Pulido 2001, Storto et al. 2001, Hu et al. 2004, Takarada et al. 2004, Marciniak et al. 2016). We recently demonstrated the expression of GluA1 and GluA2/3 (AMPAR subunits) in the mouse interstitial tissue and SPG (Santillo et al. 2019). Moreover, we reported that D-Asp affects both GluA1 and GluA2/3 AMPAR subunits in mouse GC-1 spermatogonial cells (Santillo et al. 2019). According to a previous report (Gill et al. 2000), we found GluA2/3 subunit to be localized in both LC and germinal epithelium, prevalently in the SPG of the rat testis. Furthermore, the results obtained with in vivo experiments demonstrated that D-Asp elicited an increase in the expression of GluA2/3 protein. Finally, the immunofluorescent analyses demonstrated congruence between PREP and GluA2/3 distributions in the rat testis. It is well known that AMPAR is permeable to calcium and other cations, such as sodium and potassium, and this permeability is governed by the GluA2 subunit. Since PREP acts as a possible regulator of the pathway of inositol 1,4,5, which modulates the cytosolic calcium levels (Szeltner \& Polgár 2008, Venditti et al. 2019), we hypothesize that PREP might be a possible key player in the AMPAR-dependent activation of molecular pathway elicited by D-Asp in the rat testis by mediating calcium signaling.

Interestingly, immunofluorescence data showed that the intermediate yellow-orange tint areas were rare, suggesting that the co-localization ratio between PREP and GluA2/3 in the testicular tubules was very low. Probably this could be due to the fact that, although they are expressed in the same cells, and in particular in the interstitial LC, PREP and GluA2/3 have different cellular sub-localization, being a cytoplasmic and membrane protein respectively. Though, further studies are needed to clarify if they physically interact, that is a focus beyond the aim of this paper.

However, the demonstration that D-Asp binds AMPAR will require an in-depth study with several in vivo and in vitro experiments using specific agonists and antagonists tested at different concentrations and different exposure times.

In addition to the aforementioned role exerted by PREP, the peptidase is essential for ERK and Akt pathway activations (Duan et al. 2014, Xu et al. 2019). Interestingly, herein, we also demonstrated that the chronic D-Asp treatment induced the phosphorylation of ERK $1 / 2$ and Akt proteins in the rat testis. The acute experiment indicated that the activation of these proteins occurred after $2 \mathrm{~h}$. Moreover, levels of $\mathrm{p}$-ERK remained high $5 \mathrm{~h}$ after the treatment, whereas $\mathrm{p}$-Akt returned to its initial values. Immunofluorescence co-localization data confirmed the two proteins showed a comparable localization pattern as GluA2/3, and in particular in LC and SPG, suggesting their interaction in these cells. It is well known that ERK and Akt pathways regulate multiple biological functions including gene expression and cell cycle (Coffer et al. 1998, Vogiatzi \& Giordano 2007 ) and that, in the testis, they play a pivotal role in SPG proliferation (Chieffi et al. 2002, Stabile et al. 2006, Braydich-Stolle et al. 2007, Chieffi \& Chieffi 2013, Hasegawa et al. 2013). In accordance with our previous study, we demonstrated that treatment of GC-1 cells with D-Asp induced a rapid increase in ERK1/2 and Akt phosphorylation that, consequently, led to an increase in the protein expression of mitotic markers, such as PCNA 
and Aurora B. Keeping in mind that D-Asp exerted its action via AMPAR and that, as aforementioned, PREP may be involved in such activation, all these findings indicate that D-Asp could play a direct role in the spermatogenesis by activating ERK $1 / 2$ and Akt kinase pathways through elevated expression levels of PREP protein. Numerous previous in vivo and in vitro studies demonstrated that D-Asp modulates reproductive functions by acting at multiple levels: (1) it can affect the secretion of GnRH by acting at the hypothalamic level, generating an indirect cascade role on the hypothalamicpituitary axis; (2) a direct action on pituitary is possible, since D-Asp regulates pituitary hormone secretions and (3) it has a local role on gonads, directly inducing sex steroid hormone secretion (progesterone, testosterone, $17 \beta$-estradiol) and therefore modulating the reproductive functions through steroidogenesis (D'Aniello 2007, Di Fiore et al. 2014, 2016a,b) Therefore the increased expression of both PREP and GluA2/3 as well as the activation of ERK and Akt could be mediated by D-Asp either directly on the testis or indirectly through the hypothalamic-pituitary-gonad axis.

In conclusion, the present study is the first of its kind whose results demonstrated that acute and chronic treatments with D-Asp elicited increased expression of GluA2/3 and PREP proteins and elevated phosphorylation of ERK1/2 and Akt proteins in the rat testis. Although these findings undoubtedly require further investigation, we could safely hypothesize that D-Asp has a pivotal role in GC differentiation through the activation of PREP and AMPAR. Finally, PREP could be a major player in regulating hormone homeostasis following D-Asp treatment.

\section{Supplementary data}

This is linked to the online version of the paper at https://doi.org/10.1530/REP-19-0204.

\section{Declaration of interest}

The authors declare that there is no conflict of interest that could be perceived as prejudicing the impartiality of the research reported.

\section{Funding}

The authors received a financial support for the research, authorship and publication of this article by the Dipartimento di Medicina Sperimentale, Università degli Studi della Campania 'Luigi Vanvitelli', Napoli, Italy (2018).

\section{Author contribution statement}

A $S$ designed experiments and co-wrote the paper. $\mathrm{M} \mathrm{V}$ performed immunofluorescence analyses and co-wrote the paper. S M co-wrote the paper and provided critical revision of the article. G C B designed experiments and provided critical revision of the article. S F performed Western blot experiments and analyzed the relative data. $L R$ performed Western blot experiments and analyzed the relative data. $\mathrm{MM}$ D F supervised the research and provided final approval of the version to submit.

\section{References}

Braydich-Stolle L, Kostereva N, Dym M \& Hofmann MC 2007 Role of Src family kinases and N-Myc in spermatogonial stem cell proliferation. Developmental Biology 304 34-45. (https://doi.org/10.1016/j. ydbio.2006.12.013)

Burrone L, Di Giovanni M, Di Fiore MM, Baccari GC \& Santillo A 2010 Effects of D-aspartate treatment on D-aspartate oxidase, superoxide dismutase, and caspase 3 activities in frog (Rana esculenta) tissues. Chemistry and Biodiversity 7 1459-1466. (https://doi.org/10.1002/ cbdv.200900331)

Burrone L, Santillo A, Pinelli C, Chieffi Baccari GC \& Di Fiore MM 2012 Induced synthesis of P450 aromatase and $17 \beta$-estradiol by D-aspartate in frog brain. Journal of Experimental Biology 215 3559-3565. (https:// doi.org/10.1242/jeb.073296)

Chemek M, Venditti M, Boughamoura S, Mimouna SB, Messaoudi I \& Minucci S 2018 Involvement of testicular DAAM1 expression in zinc protection against cadmium-induced male rat reproductive toxicity. Journal of Cellular Physiology 233 630-640. (https://doi.org/10.1002/jcp.25923)

Chieffi P \& Chieffi S 2013 Molecular biomarkers as potential targets for therapeutic strategies in human testicular germ cell tumors: an overview. Journal of Cellular Physiology 228 1641-1646. (https://doi.org/10.1002/ jср.24328)

Chieffi P, Colucci D'Amato L, Guarino F, Salvatore G \& Angelini F 2002 $17 \beta$-Estradiol induces spermatogonial proliferation through mitogenactivated protein kinase (extracellular signal-regulated kinase 1) activity in the lizard (Podarcis s. sicula). Molecular Reproduction and Development 61 218-225. (https://doi.org/10.1002/mrd.1151)

Coffer PJ, Jin J \& Woodgett JR 1998 Protein kinase B (c-Akt): a multifunctional mediator of phosphatidylinositol 3-kinase activation. Biochemical Journal 335 1-13. (https://doi.org/10.1042/bj3350001)

D'Aniello A 2007 D-Aspartic acid: an endogenous amino acid with an important neuroendocrine role. Brain Research Reviews 53 215-234. (https://doi.org/10.1016/j.brainresrev.2006.08.005)

D'Aniello A \& Giuditta A 1977 Identification of D-aspartic acid in the brain of Octopus vulgaris Lam. Journal of Neurochemistry 29 10531057. (https://doi.org/10.1111/j.1471-4159.1977.tb06508.x)

D'Aniello A, Di Fiore MM, D'Aniello G, Colin FE, Lewis G \& Setchell BP 1998 Secretion of D-aspartic acid by the rat testis and its role in endocrinology of the testis and spermatogenesis. FEBS Letters $43623-$ 27. (https://doi.org/10.1016/s0014-5793(98)01087-4)

D'Aniello A, Di Fiore MM, Fisher GH, Milone A, Seleni A, D'Aniello S, Perna AF \& Ingrosso D 2000a Occurrence of D-aspartic acid and $\mathrm{N}$-methyl-D-aspartic acid in rat neuroendocrine tissues and their role in the modulation of luteinizing hormone and growth hormone release. FASEB Journal 14 699-714. (https://doi.org/10.1096/fasebj.14.5.699)

D'Aniello G, Tolino A, D'Aniello A, Errico F, Fisher GH \& Di Fiore MM $2000 b$ The role of D-aspartic acid and N-methyl-D-aspartic acid in the regulation of prolactin release. Endocrinology 141 3862-3870. (https:// doi.org/10.1210/endo.141.10.7706)

D'Aniello G, Ronsini S, Guida F, Spinelli P \& D'Aniello A 2005 Occurrence of D-aspartic acid in human seminal plasma and spermatozoa: possible role in reproduction. Fertility and Sterility 84 1444-1449. (https://doi. org/10.1016/j.fertnstert.2005.05.019)

D'Aniello S, Somorjai I, Garcia-Fernàndez J, Topo E \& D'Aniello A 2011 $\mathrm{D}$-aspartic acid is a novel endogenous neurotransmitter. FASEB Journal 25 1014-1027. (https://doi.org/10.1096/fj.10-168492)

Di Fiore MM, Santillo A \& Chieffi Baccari G 2014 Current knowledge of D-aspartate in glandular tissues. Amino Acids 46 1805-1818. (https:// doi.org/10.1007/s00726-014-1759-2)

Di Fiore MM, Burrone L, Santillo A \& Chieffi Baccari G 2016a Endocrine activity of D-aspartate in nonmammalian animals. In D-Amino Acids: 
Physiology, Metabolism, and Application, pp 157-172. Eds T Yoshimura, T Nishikawa \& H Homma. Japan: Springer.

Di Fiore MM, Santillo A, Falvo S, Longobardi S \& Chieffi Baccari G 2016 b Molecular mechanisms elicited by D-aspartate in leydig cells and spermatogonia. International Journal of Molecular Sciences 17 E1127. (https://doi.org/10.3390/ijms17071127)

Di Fiore MM, Santillo A, Falvo S, Chieffi Baccari G, Venditti M, Di Giacomo Russo F, Lispi M \& D'Aniello A 2018 Sex hormone levels in the brain of d-aspartate-treated rats. Comptes Rendus Biologies 341 9-15. (https://doi.org/10.1016/j.crvi.2017.11.002)

Di Giovanni M, Burrone L, Chieffi Baccari G, Topo E \& Santillo A 2010a Distribution of free D-aspartic acid and D-aspartate oxidase in frog Rana esculenta tissues. Journal of Experimental Zoology: Part A, Ecological Genetics and Physiology 313 137-143. (https://doi.org/10.1002/jez.585)

Di Giovanni M, Topo E, Santillo A, D'Aniello A \& Chieffi Baccari G 2010 b D-aspartate binding sites in rat harderian gland. Amino Acids 38229 235. (https://doi.org/10.1007/s00726-008-0231-6)

Dingledine R, Borges K, Bowie D \& Traynelis SF 1999 The glutamate receptor ion channels. Pharmacological Reviews 51 7-61.

Dotolo R, Kim JD, Pariante P, Minucci S \& Diano S 2016 Prolyl endopeptidase (PREP) is associated with male reproductive functions and gamete physiology in mice. Journal of Cellular Physiology 231551 557. (https://doi.org/10.1002/jcp.25178)

Duan L, Ying G, Danzer B, Perez RE, Shariat-Madar Z, Levenson VV \& Maki CG 2014 The prolyl peptidases PRCP/PREP regulate IRS-1 stability critical for rapamycin-induced feedback activation of PI3K and AKT. Journal of Biological Chemistry 289 21694-21705. (https://doi. org/10.1074/jbc.M114.550038)

Falvo S, Di Fiore MM, Burrone L, Chieffi Baccari GC, Longobardi S \& Santillo A 2016 Androgen and oestrogen modulation by D-aspartate in rat epididymis. Reproduction, Fertility, and Development 28 1865-1872. (https://doi.org/10.1071/RD15092)

Gill SS \& Pulido OM 2001 Glutamate receptors in peripheral tissues: current knowledge, future research, and implications for toxicology. Toxicologic Pathology 29 208-223. (https://doi.org/10.1080/019262301317052486)

Gill SS, Mueller RW, McGuire PF \& Pulido OM 2000 Potential target sites in peripheral tissues for excitatory neurotransmission and excitotoxicity. Toxicologic Pathology 28 277-284. (https://doi. org/10.1177/019262330002800207)

Griswold MD 2016 Spermatogenesis: the commitment to meiosis. Physiological Reviews $96 \quad 1-17 . \quad$ (https://doi.org/10.1152/ physrev.00013.2015)

Hasegawa K, Namekawa SH \& Saga Y 2013 MEK/ERK signaling directly and indirectly contributes to the cyclical self-renewal of spermatogonial stem cells. Stem Cells 31 2517-2527. (https://doi.org/10.1002/stem.1486)

Hu JH, Yang N, Ma YH, Jiang J, Zhang JF, Fei J \& Guo LH 2004 Identification of glutamate transporters and receptors in mouse testis. Acta Pharmacologica Sinica 25 366-371.

Ishino T, Ohtsuki S, Homma Ki \& Natori S 1998 cDNA cloning of mouse prolyl endopeptidase and its involvement in DNA synthesis by Swiss 3T3 cells. Journal of Biochemistry 123 540-545. (https://doi.org/10.1093/ oxfordjournals.jbchem.a021970)

Izzo G, Ferrara D, Napolitano F, Crispo AA, d'Istria M, Aniello F \& Minucci S 2011 Identification of a cDNA encoding for ghrelin in the testis of the frog Pelophylax esculentus and its involvement in spermatogenesis. Comparative Biochemistry and Physiology: Part A, Molecular and Integrative Physiology 158 367-373. (https://doi. org/10.1016/j.cbpa.2010.09.005)

Kimura A, Ohnishi J, Okimura H, Hamabata T \& Takahashi T 1998 Localization of prolyl endopeptidase mRNA in small growing follicles of porcine ovary. Molecular Reproduction and Development $50121-$ 127. (https://doi.org/10.1002/(SICI)1098-2795(199806)50:2<121::AIDMRD1>3.0.CO;2-M)

Kimura A, Matsui H \& Takahashi T 2002 Expression and localization of prolyl oligopeptidase in mouse testis and its possible involvement in sperm motility. Zoological Science 19 93-102. (https://doi.org/10.2108/ zsj.19.93)

Lamanna C, Assisi L, Botte V \& Di Fiore MM 2007a Involvement of D-Asp in P450 aromatase activity and estrogen receptors in boar testis. Amino Acids 32 45-51. (https://doi.org/10.1007/s00726-006-0351-9)

Lamanna C, Assisi L, Vittoria A, Botte V \& Di Fiore MM 2007b $\mathrm{D}$-aspartic acid and nitric oxide as regulators of androgen production in boar testis. Theriogenology 67 249-254. (https://doi.org/10.1016/j. theriogenology.2006.07.016)

Lew RA, Tetaz TJ, Glucksman MJ, Roberts JL \& Smith AI 1994 Evidence for a two-step mechanism of gonadotropin-releasing hormone metabolism by prolyl endopeptidase and metalloendopeptidase EC 3.4.24.15 in ovine hypothalamic extracts. Journal of Biological Chemistry 269 12626-12632.

Marciniak M, Chruścicka B, Lech T, Burnat G \& Pilc A 2016 Expression of group III metabotropic glutamate receptors in the reproductive system of male mice. Reproduction, Fertility, and Development 28 369-374. (https://doi.org/10.1071/RD14132)

Mentlein R 1988 Proline residues in the maturation and degradation of peptide hormones and neuropeptides. FEBS Letters 234 251-256. (https://doi.org/10.1016/0014-5793(88)80092-9)

Monteforte R, Santillo A, Chieffi P \& Chieffi Baccari G 2007 D-aspartate in frog harderian gland. In D-Amino Acids: A New Frontier in Amino Acid and Protein Research - Practical Methods and Protocols, pp 215-220. Eds R Konno, H Brückner, A D’Aniello, G Fisher, N Fujii \& H Homma. New York: Nova Science Publishers.

Monteforte R, Santillo A, Di Giovanni M, D'Aniello A, Di Maro A \& Chieffi Baccari G 2009 D-aspartate affects secretory activity in rat harderian gland: molecular mechanism and functional significance. Amino Acids 37 653-664. (https://doi.org/10.1007/s00726-008-0185-8)

Myöhänen TT, Pyykkö E, Männistö PT \& Carpen O 2012 Distribution of prolyl oligopeptidase in human peripheral tissues and in ovarian and colorectal tumors. Journal of Histochemistry and Cytochemistry $60706-$ 715. (https://doi.org/10.1369/0022155412453051)

Nagata Y, Homma H, Lee JA \& Imai K 1999a D-aspartate stimulation of testosterone synthesis in rat Leydig cells. FEBS Letters 444 160-164. (https://doi.org/10.1016/s0014-5793(99)00045-9)

Nagata Y, Homma H, Matsumoto M \& Imai K 1999b Stimulation of steroidogenic acute regulatory (StAR) gene expression by Daspartate in rat Leydig cells. FEBS Letters 454 317-320.

Nishimura H \& L'Hernault SW 2017 Spermatogenesis. Current Biology 27 R988-R994. (https://doi.org/10.1016/j.cub.2017.07.067)

Ohtsuki S, Homma K, Kurata S \& Natori S 1997 Molecular cloning of cDNA for Sarcophaga prolyl endopeptidase and characterization of the recombinant enzyme produced by an E. coli expression system. Insect Biochemistry and Molecular Biology 27 337-343. (https://doi. org/10.1016/S0965-1748(97)00004-0)

Pariante P, Dotolo R, Venditti M, Ferrara D, Donizetti A, Aniello F \& Minucci S 2016 First evidence of DAAM1 localization during the post-natal development of rat testis and in mammalian sperm. Journal of Cellular Physiology $2312172-2184 . \quad$ (https://doi.org/10.1002/ jcp.25330)

Pereira VM, Reis FM, Santos RA, Cassali GD, Santos SH, HonoratoSampaio K \& dos Reis AM 2009 Gonadotropin stimulation increases the expression of angiotensin-(1-7) and MAS receptor in the rat ovary. Reproductive Sciences 16 1165-1174. (https://doi. org/10.1177/1933719109343309)

Raucci F \& Di Fiore MM 2009 The reproductive activity in the testis of Podarcis s. sicula involves D-aspartic acid: a study on c-kit receptor protein, tyrosine kinase activity and PCNA protein during annual sexual cycle. General and Comparative Endocrinology 161 373-383. (https:// doi.org/10.1016/j.ygcen.2009.02.002)

Raucci F, Santillo A, D'Aniello A, Chieffi P \& Chieffi Baccari GC 2005 D-aspartate modulates transcriptional activity in harderian gland of frog, Rana esculenta: morphological and molecular evidence. Journal of Cellular Physiology 204 445-454. (https://doi.org/10.1002/jcp.20316)

Sakai K, Homma H, Lee JA, Fukushima T, Santa T, Tashiro K, Iwatsubo T \& Imai K 1998 Localization of D-aspartic acid in elongate spermatids in rat testis. Archives of Biochemistry and Biophysics 351 96-105. (https:// doi.org/10.1006/abbi.1997.0539)

Santillo A, Monteforte R, Raucci F, D'Aniello A \& Chieffi Baccari G 2006 Occurrence of D-aspartate in the harderian gland of Podarcis s. sicula and its effect on gland secretion. Journal of Experimental Zoology A 305 610-619.

Santillo A, Burrone L, Senese R, Cioffi F, Lanni A \& Chieffi Baccari G 2011 Effect of D-aspartate uptake on uncoupling protein-3 and $\alpha$-tubulin expressions in rat harderian gland. Journal of Chromatography. B, Analytical Technologies in the Biomedical and Life Sciences 8793344 3348. (https://doi.org/10.1016/j.jchromb.2011.04.001) 
Santillo A, Pinelli C, Burrone L, Chieffi Baccari G \& Di Fiore MM 2013 D-aspartic acid implication in the modulation of frog brain sex steroid levels. General and Comparative Endocrinology 181 72-76. (https://doi. org/10.1016/j.ygcen.2012.11.003)

Santillo A, Falvo S, Chieffi P, Burrone L, Chieffi Baccari G, Longobardi S \& Di Fiore MM 2014 D-aspartate affects NMDA receptor-extracellular signal-regulated kinase pathway and upregulates androgen receptor expression in the rat testis. Theriogenology 81 744-751. (https://doi. org/10.1016/j.theriogenology.2013.12.009)

Santillo A, Falvo S, Chieffi P, Di Fiore MM, Senese R \& Chieffi Baccari G 2016 D-aspartate induces proliferative pathways in spermatogonial GC-1 cells. Journal of Cellular Physiology 231 490-495. (https://doi. org/10.1002/jcp.25095)

Santillo A, Chieffi Baccari G, Falvo S, Di Giacomo Russo F, Venditti M \& Di Fiore MM 2018 Effects of D-aspartate on sex hormone-dependent tissues in pelophylax esculentus. In Amphibians: Biology, Ecology and Conservation, pp 21-37. Ed L Cannon. New York: Nova Science Publishers.

Santillo A, Falvo S, Di Fiore MM, Di Giacomo Russo F, Chieffi P, Usiello A, Pinelli C \& Baccari GC 2019 AMPA receptor expression in mouse testis and spermatogonial GC-1 cells: a study on its regulation by excitatory amino acids. Journal of Cellular Biochemistry 12011044-11055. (https:// doi.org/10.1002/jcb.28382)

Schlatt S \& Ehmcke J 2014 Regulation of spermatogenesis: an evolutionary biologist's perspective. Seminars in Cell and Developmental Biology 29 2-16. (https://doi.org/10.1016/j.semcdb.2014.03.007)

Spinelli P, Brown ER, Ferrandino G, Branno M, Montarolo PG, D'Aniello E, Rastogi RK, D'Aniello B, Baccari GC, Fisher G et al. 2006 D-aspartic acid in the nervous system of Aplysia Limacina: possible role in neurotransmission. Journal of Cellular Physiology 206 672-681. (https:// doi.org/10.1002/jcp.20513)

Stabile V, Russo M \& Chieffi P 2006 17Beta-estradiol induces Akt-1 through estrogen receptor-beta in the frog (Rana esculenta) male germ cells. Reproduction 132 477-484. (https://doi.org/10.1530/rep.1.01107)

Storto $M$, Sallese $M$, Salvatore L, Poulet R, Condorelli DF, Dell'Albani $P$, Marcello MF, Romeo R, Piomboni P, Barone N et al. 2001 Expression of metabotropic glutamate receptors in the rat and human testis. Journal of Endocrinology 170 71-78. (https://doi.org/10.1677/joe.0.1700071)

Szeltner Z \& Polgár L 2008 Structure, function and biological relevance of prolyl oligopeptidase. Current Protein and Peptide Science 9 96-107. (https://doi.org/10.2174/138920308783565723)

Takarada T, Hinoi E, Balcar VJ, Taniura H \& Yoneda Y 2004 Possible expression of functional glutamate transporters in the rat testis. Journal of Endocrinology 181 233-244. (https://doi.org/10.1677/joe.0.1810233)

Tomita K, Tanaka H, Kageyama S, Nagasawa M, Wada A, Murai R, Kobayashi K, Hanada E, Agata Y \& Kawauchi A 2016 The effect of $\mathrm{D}$-aspartate on spermatogenesis in mouse testis. Biology of Reproduction 94 30. (https://doi.org/10.1095/biolreprod.115.134692)

Tonellotto dos Santos J, Ferreira R, Gasperin BG, Siqueira LC, de Oliveira JF, Santos RA, Reis AM \& Gonçalves PB 2012 Molecular characterization and regulation of the angiotensin-converting enzyme type 2/angiotensin-(1-7)/MAS receptor axis during the ovulation process in cattle. Journal of the Renin-Angiotensin-Aldosterone System 13 91-98. (https://doi.org/10.1177/1470320311417273)

Topo E, Soricelli A, D'Aniello A, Ronsini S \& D'Aniello G 2009 The role and molecular mechanism of $\mathrm{D}$-aspartic acid in the release and synthesis of $\mathrm{LH}$ and testosterone in humans and rats. Reproductive Biology and Endocrinology 7 120. (https://doi.org/10.1186/1477-7827-7-120)
Topo E, Fisher G, Sorricelli A, Errico F, Usiello A \& D'Aniello A 2010 Thyroid hormones and D-aspartic acid, D-aspartate oxidase, D-aspartate racemase, $\mathrm{H} 2 \mathrm{O} 2$, and $\mathrm{ROS}$ in rats and mice. Chemistry and Biodiversity 7 1467-1478.

Valdivia A, Irazusta J, Fernández D, Múgica J, Ochoa C \& Casis L 2004 Pyroglutamyl peptidase I and prolyl endopeptidase in human semen: increased activity in necrozoospermia. Regulatory Peptides 122 79-84. (https://doi.org/10.1016/j.regpep.2004.05.005)

Venditti M \& Minucci S 2017 Prothymosin alpha expression in the vertebrate testis: a comparative review. Zygote 25 760-770. (https://doi. org/10.1017/S096719941700065X)

Venditti M \& Minucci S 2019 Subcellular localization of prolyl endopeptidase during the first wave of rat spermatogenesis and in rat and human sperm. Journal of Histochemistry and Cytochemistry 67 229-243. (https://doi.org/10.1369/0022155418810064)

Venditti M, Fasano C, Santillo A, Aniello F \& Minucci S 2018 First evidence of DAAM1 localization in mouse seminal vesicles and its possible involvement during regulated exocytosis. Comptes Rendus Biologies 341 228-234. (https://doi.org/10.1016/j.crvi.2018.03.001)

Venditti M, Aniello F, Santillo A \& Minucci S 2019 Study on PREP localization in mouse seminal vesicles and its possible involvement during regulated exocytosis. Zygote 27 160-165. (https://doi. org/10.1017/S0967199419000194)

Vogiatzi P \& Giordano A 2007 Following the tracks of AKT1 gene. Cancer Biology and Therapy 6 1521-1524. (https://doi.org/10.4161/ cbt.6.10.4834)

Wilk S 1983 Prolyl endopeptidase. Life Sciences 33 2149-2157. (https:// doi.org/10.1016/0024-3205(83)90285-0)

Xu P, Bao R, Zhang Y, Lu E, Feng F, Zhang L, Li J, Wang J, Tan X, Tang M et al. 2019 Prolyl oligopeptidase regulates progesterone secretion via the ERK signaling pathway in murine luteal cells. Molecular Reproduction and Development 86 714-726. (https://doi.org/10.1002/mrd.23149)

Yamanaka C, Lebrethon MC, Vandersmissen E, Gerard A, Purnelle G, Lemaitre M, Wilk S \& Bourguignon JP 1999 Early prepubertal ontogeny of pulsatile gonadotropin-releasing hormone $(\mathrm{GnRH})$ secretion: I. Inhibitory autofeedback control through prolyl endopeptidase degradation of GnRH. Endocrinology 140 4609-4615. (https://doi. org/10.1210/endo.140.10.6971)

Yokosawa H, Miyata M, Sawada H \& Ishii S 1983 Isolation and characterization of a post-proline cleaving enzyme and its inhibitor from sperm of the ascidian, Halocynthia roretzi. Journal of Biochemistry 94 1067-1076. (https://doi.org/10.1093/oxfordjournals. jbchem.a134449)

Yoshida K, Inaba K, Ohtake H \& Morisawa M 1999 Purification and characterization of prolyl endopeptidase from the Pacific herring, Clupea pallasi, and its role in the activation of sperm motility. Development, Growth and Differentiation 41 217-225. (https://doi.org/10.1046/ j.1440-169x.1999.00424.x)

Received 7 May 2019

First decision 3 June 2019

Revised manuscript received 6 August 2019

Accepted 9 August 2019 